\title{
Ondas mecânicas: uma proposta de sequência didática utilizando recursos e elementos motivacionais alternativos
}

\author{
Bruno Ferreira de Araújo ${ }^{1}$, Luciene Batista da Silveira² ${ }^{2}$ \\ 1 Instituto Federal do Acre (IFAC) \\ ${ }^{2}$ Fundação Universidade Federal de Rondônia (UNIR)
}

Palavras-Chave: Ensino de Física, ondas, experimentação, simulador computacional.

\section{Introdução}

O ensino de Ciência, em especial, do componente curricular de Física é um tema que ao longo dos anos vem sendo discutido nos mais variados níveis e modalidades de ensino. Muitos estudos encontrados na literatura indicam a importância de tornar o ensino desse componente mais dinâmico e significativo para o aluno. Mas como fazer isso? Ausubel et al. (1980) propõe "Descubra o que ele (aluno) sabe e baseie nisso os seus ensinamentos" Ausubel et al. (1980, p. 8), enquanto sobre o tema motivação, Tapia e Fita (1999) afirmam que no processo ensino-aprendizagem a motivação deve estar presente em todos os momentos, por isso, muitas vezes dizemos que para o aluno ter motivação para a aprendizagem, é importante ter um bom professor.

Pensando nessa problemática, este trabalho traz uma proposta de sequência didática sobre o tema ondas mecânicas, em específico os tópicos: natureza, classificação e propriedades gerais das ondas, intensidade, ressonância, timbre e altura do som utilizando recursos e elementos motivacionais alternativos como: experimentação de baixo custo, simulações computacionais, mapas conceituais, vídeos e textos interdisciplinares para alunos do $2^{\circ}$ ano do Ensino Médio de uma escola Estadual localizada no Município de Porto Velho - RO. Através dos resultados obtidos com a aplicação dessa proposta foi possível verificar, por meio de questionários, verificação de aprendizagem e relatos, o grau de conhecimentos adquiridos dos discentes participantes da pesquisa e a sua respectiva aceitação.

\section{Metodologia e materiais}

Para a execução da proposta investigativa que definimos, selecionamos a Escola Pública Estadual que recebe alunos do Ensino Fundamental e Médio Barão dos Solimões, localizada na região central da cidade de Porto Velho - RO. As atividades desta pesquisa tiveram início no primeiro semestre de 2016, onde escolhemos uma turma de 28 alunos que cursavam a segunda série do ensino médio regular vespertino e se estenderam até julho do mesmo ano. Os procedimentos iniciais estão elencados na representação da Figura 1:

Figura 1: Representação dos procedimentos iniciais.

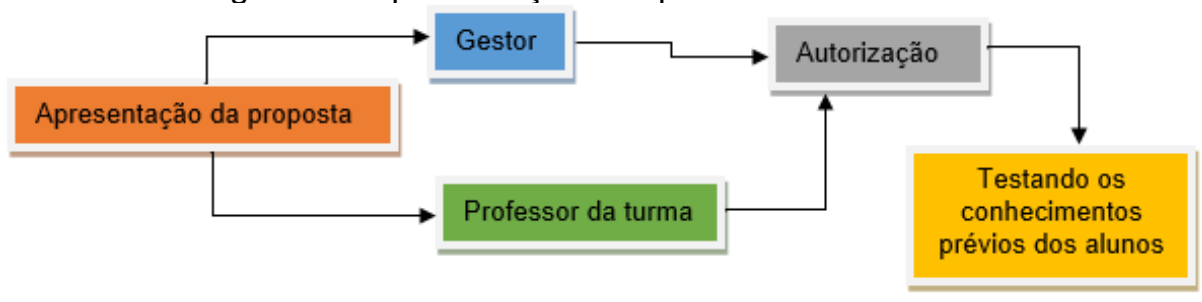

Conhecendo os conhecimentos prévios dos alunos, elaboramos uma série de procedimentos que contemplou metodologias alternativas de ensino conforme propunha o projeto.

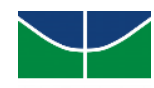




\begin{tabular}{|c|c|c|}
\hline PI & ELEMENTOS & SEQUÊNCIA DIDÁTICA \\
\hline$>1$ & IOS & de material de \\
\hline $\begin{array}{l}\text { S Seleção de conteúdos; } \\
\text { > Quantitativo de aulas; } \\
\text { > Sondagem e avaliação; }\end{array}$ & $\begin{array}{l}>\text { Motivacional; } \\
>\text { Recursos didáticos; } \\
>\text { Contextualização; }\end{array}$ & $\begin{array}{l}\text { apoio ao docente; } \\
\text { Aplicação do material de } \\
\text { apoio; }\end{array}$ \\
\hline
\end{tabular}

Figura 2: Esquema para elaboração da sequência didática.

No que tange a elaboração da sequência didática, os elementos hierárquicos da Figura 2 mostra os itens que consideramos para a sua produção e reprodução.

\section{Resultados e discussão}

O tema escolhido a ser trabalhado nesta pesquisa se justifica por dois aspectos: $O$ primeiro está associado em motivar o aluno para a aprendizagem. O segundo, por acreditar que o ensino de Física precisa ser modificado em sua raiz, onde devemos explorar diversas metodologias que possibilitem ao estudante entender que a Física é uma ciência que está inserida em seu cotidiano.

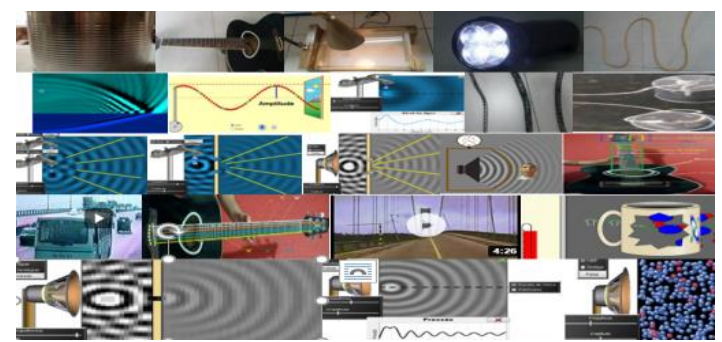

Figura 3: Recursos e elementos motivacionais.

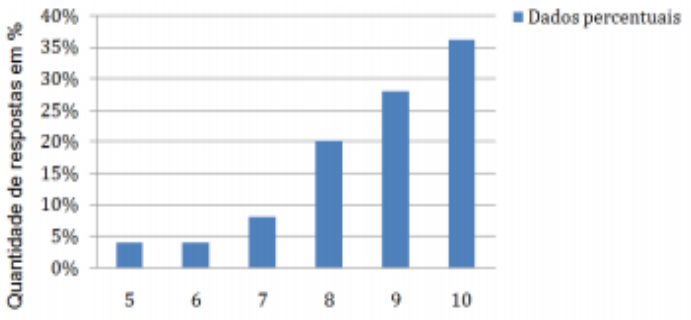

Figura 4: Percentual de grau de satisfação.

A Figura 3 demonstra o quantitativo de variações didáticos-instrumentais foram utilizadas no decorrer das aulas, enquanto a Figura 4 mostram o percentual do grau de satisfação dos discentes participantes da atividade.

\section{Conclusões}

A proposta de sequência didática pode ser elaborada para trabalhar outros temas da grade curricular de Física em que seja possível utilizar recursos alternativos para tornar a Física uma disciplina mais atraente para os alunos e assim os motivar para praticar e aprender. A inclusão dos recursos alternativos na sequência didática possibilitou aos alunos serem o construtor dos seus próprios conhecimentos, vide que a partir do momento que lhe entregamos a oportunidade de criar hipóteses para a resolução de problemas, estivemos estimulando a pensar, refletir e portanto, possibilitando o despertar do conhecimento e potencializando a sua criatividade.

À Capes pela bolsa de estudos.

\section{Agradecimentos}

\section{Referências}

AUSUBEL, D. P. Psicologia educacional. Rio de Janeiro, Interamericana. Tradução ao português, de Eva Nick et al., da segunda edição de Educational psychology: a cognitive view. 1980. TAPIA, J. A.; FITA, E. C.. A motivação em sala da aula: o que é, como se faz. São Paulo: Loyola, 1999.

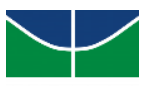

